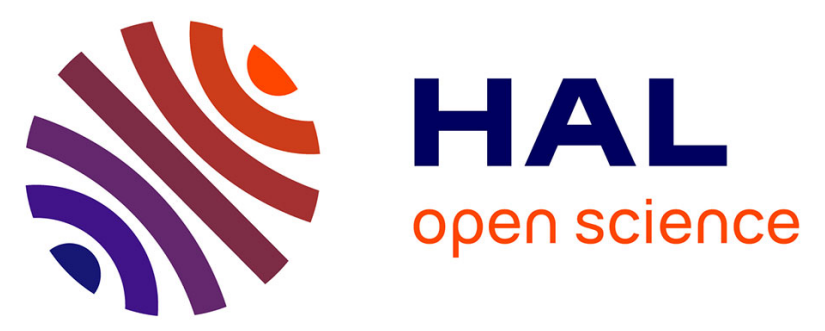

\title{
Immunohistochemical investigation of tumorigenic pathways in sinonasal intestinal-type adenocarcinoma. A tissue microarray analysis of 62 cases.
}

Alessandro Franchi, Annarita Palomba, Cristina Fondi, Lucia Miligi, Milena Paglierani, Monica Pepi, Marco Santucci

\section{To cite this version:}

Alessandro Franchi, Annarita Palomba, Cristina Fondi, Lucia Miligi, Milena Paglierani, et al.. Immunohistochemical investigation of tumorigenic pathways in sinonasal intestinal-type adenocarcinoma. A tissue microarray analysis of 62 cases.. Histopathology, 2011, 59 (1), pp.98. 10.1111/j.13652559.2011.03887.x . hal-00651160

\author{
HAL Id: hal-00651160 \\ https://hal.science/hal-00651160
}

Submitted on 13 Dec 2011

HAL is a multi-disciplinary open access archive for the deposit and dissemination of scientific research documents, whether they are published or not. The documents may come from teaching and research institutions in France or abroad, or from public or private research centers.
L'archive ouverte pluridisciplinaire HAL, est destinée au dépôt et à la diffusion de documents scientifiques de niveau recherche, publiés ou non, émanant des établissements d'enseignement et de recherche français ou étrangers, des laboratoires publics ou privés. 


\section{Histopathology}

\section{Immunohistochemical investigation of tumorigenic pathways in sinonasal intestinal-type adenocarcinoma. A tissue microarray analysis of 62 cases.}

\begin{tabular}{|c|c|}
\hline Journal: & Histopathology \\
\hline Manuscript ID: & HISTOP-10-10-0542.R1 \\
\hline Wiley - Manuscript type: & Original Article \\
\hline $\begin{array}{l}\text { Date Submitted by the } \\
\text { Author: }\end{array}$ & 22-Jan-2011 \\
\hline Complete List of Authors: & $\begin{array}{l}\text { Franchi, Alessandro; University of Florence, Division of Anatomic } \\
\text { Pathology, Department of Critical Care Medicine and Surgery, } \\
\text { University of Florence Medical School } \\
\text { Palomba, Annarita; Azienda Ospedaliera Universitaria Careggi, Unit } \\
\text { of Histopathology } \\
\text { Fondi, Cristina; University of Florence, Division of Anatomic } \\
\text { Pathology, Department of Critical Care Medicine and Surgery, } \\
\text { University of Florence Medical School } \\
\text { Miligi, Lucia; Unit of Environmental and Occupational Epidemiology, } \\
\text { ISPO - Cancer Prevention and Research Institute } \\
\text { paglierani, milena; Azienda Ospedaliera Universitaria Careggi, Unit } \\
\text { of Histopathology } \\
\text { Pepi, Monica; University of Florence, Division of Anatomic } \\
\text { Pathology, Department of Critical Care Medicine and Surgery, } \\
\text { University of Florence Medical School } \\
\text { Santucci, Marco; University of Florence, Division of Anatomic } \\
\text { Pathology, Department of Critical Care Medicine and Surgery, } \\
\text { University of Florence Medical School }\end{array}$ \\
\hline Keywords: & $\begin{array}{l}\text { nasal cavity, adenocarcinoma, intestinal type, } \\
\text { immunohistochemistry, oncogene products }\end{array}$ \\
\hline
\end{tabular}

\section{SCHOLARONE Manuscripts}




\title{
Immunohistochemical investigation of tumorigenic pathways in sinonasal
} intestinal-type adenocarcinoma. A tissue microarray analysis of 62 cases.

\author{
Alessandro Franchi, ${ }^{1}$ Annarita Palomba, ${ }^{2}$ Cristina Fondi, ${ }^{1}$ \\ Lucia Miligi, ${ }^{3}$ Milena Paglierani, ${ }^{2}$ Monica Pepi, ${ }^{1}$ Marco Santucci ${ }^{1}$
}

\footnotetext{
${ }^{1}$ Division of Anatomic Pathology, Department of Critical Care Medicine and Surgery, University of Florence Medical School, Florence, Italy ${ }^{2}$ Unit of Histopathology, Azienda Ospedaliera Universitaria Careggi, Florence, Italy ${ }^{3}$ Unit of Environmental and Occupational Epidemiology, ISPO - Cancer Prevention and Research Institute, Florence, Italy
}

\section{MS HISTOP-10-10-0542}

Running title: tumorigenic pathways in sinonasal intestinal type adenocarcinoma

Key words: nasal cavity, paranasal sinuses, adenocarcinoma, intestinal type, immunohistochemistry, oncogene products

\section{Corresponding Author:}

Alessandro Franchi, MD

Division of Anatomic Pathology

Department of Critical Care Medicine and Surgery

University of Florence

Viale G.B. Morgagni 85

50134, Florence

Italy

Phone: +39 0554478102

Fax: + 390554379868

E-mail: franchi@unifi.it 


\begin{abstract}
Aims. Sinonasal intestinal type adenocarcinoma (ITAC) is an uncommon neoplasm morphologically similar to colorectal adenocarcinoma, with a well recognized association with occupational exposure to wood or leather dusts. Here, we analyse several gene products with pivotal roles in tumourigenesis, including p53, p16, deleted in colon cancer (DCC), retinoblastoma, adenomatous polyposis coli, $\beta$-catenin, E-cadherin, and CD10, and discuss their relation to clinical behaviour and to similar pathways in colorectal adenocarcinomas.
\end{abstract}

Methods and Results. Immunohistochemical analysis of 62 ITACs was conducted on a tissue microarray. Aberrant expression of $\mathrm{p} 53$ and p16 were the most commonly observed alterations ( $61.3 \%$ and $64.5 \%$ of cases, respectively). Analysis according to the histologic subtype showed that p53 overexpression was less frequent in mucinous ITACs (35.3\% vs. $71.1 \%, \mathrm{p}=0.018$ ), while loss of $\mathrm{DCC}$ and $\mathrm{E}$-cadherin were more frequently observed in this subtype $(76.5 \%$ vs. $31.1 \%, p=0.002$, and $82.4 \%$ vs $31.1 \%, p<0.001$, respectively). No correlation was found between the aberrant expression of the above mentioned proteins and clinical behavior, while mucinous adenocarcinomas had a significantly worse prognosis, with shorter disease free interval and overall survival $(p=0.005$ and $p<0.001$, respectively).

Conclusions. Mucinous ITACs appear to follow a distinct molecular pathway(s) from the non-mucinous variants, and pursue an aggressive clinical behavior. 


\section{Introduction}

Sinonasal intestinal type adenocarcinoma (ITAC) is an uncommon neoplasm morphologically similar to or indistinguishable from colorectal adenocarcinoma, with a well recognized association with occupational exposure to wood or leather dusts. ITAC shows a range of microscopic features spanning from tumors indistinguishable from typical colonic adenocarcinoma to mucinous or signet-ring cell carcinoma of the colon. ${ }^{1}$ Given the morphologic similarity, one would presume that sinonasal ITAC and colorectal adenocarcinomas might share the same or similar phenotypic and genetic features. However, data from literature indicate that this is only partially true, since a number of difference in the immunophenotypical and genetic profile have been evidenced between sinonasal ITAC and colorectal adenocarcinoma, and these observations suggest that ITAC

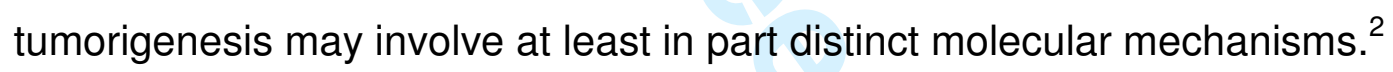

The current study was undertaken to compare the molecular pathways of tumourigenesis in sinonasal ITACs, and to discuss their relation to clinical behaviour and to similar pathways in colorectal adenocarcinomas. These included the products of the tumor suppressor genes p53, p16, deleted in colon cancer (DCC), and retinoblastoma $(\mathrm{RB})$; the adenomatous polyposis coli (APC) and $\beta$-catenin proteins, that serve key roles in the Wnt signaling pathway; and factors related to tumor aggressiveness such as Ecadherin and CD10.

\section{Materials and Methods}

\section{Patients}

In this study we investigated tumor tissue samples of ITAC from 62 patients. There were 55 males and 7 female subjects, ranging in age between 42 and 83 years (mean 63.7 years). Occupational exposure was known for 55 patients: 26 had been employed in leather industry, 16 in wood industry, and 13 worked in other productive sectors. According 
to AJCC TNM staging system (Seventh Edition, 2009), which could be determined for 54 subjects, the majority of tumors was in locally advanced stage, 14 being T3 and 19 T4 lesions. Neck lymph node metastases were present in 2 patients, while 7 had distant metastasis. Complete follow-up was available for 57 patients, ranging between 3 and 110 months, (median 38 months): 31 patients (54.4\%) experienced local recurrence and 29 $(50.9 \%)$ died of disease.

\section{Histopathology}

The diagnosis of ITAC was based on the criteria defined in the WHO classification of sinonasal adenocarcinomas. ${ }^{1}$ When deemed necessary, the diagnosis was supported by the use of immunohistochemical staining for markers of enteric differentiation, such as cytokeratin 20 and CDX-2. ${ }^{3}$

\section{Immunohistochemistry}

For tissue microarray construction, areas of interest rich in nonnecrotic tumoral glands, were identified on corresponding H\&E-stained sections and marked on the source paraffin block. The source block was cored and a $0.6 \mathrm{~mm}$ core transferred to the recipient master block using the Beecher Tissue Microarrayer (Beecher Instruments, Silver Spring, MD). Three cores from different areas of the same tissue block were arrayed for each case. Five micrometers thick sections were obtained from the block, which were stained with hematoxylin and eosin, or employed for the immunohistochemical analysis. For immunohistochemical staining, paraffin section (5 $\mu$ m thickness) were dewaxed, hydrated and after inactivation of endogenous peroxidase were immunostained using the BenchMark® XT stainer and revealed with the iVIEW DAB detection kit, yielding a brown reaction product. Table 1 reports the antibody source, dilution and antigen retrieval protocols used. After the staining run was complete, the slides were removed from autostainer, counterstained with hematoxylin, dehydrated and mounted with permanent mounting medium. As negative controls, we substituted the primary antibody with a 
Ventana dispenser filled with non immune serum at the same concentration for each immunohistochemical reaction.

Analysis of the tissue array was performed using the Spot Browser® image analysis system (Alphelys, Plaisir, France) to facilitate the matching of the tissue microarray spots with specimen identification codes. The scoring was performed by a single pathologist (A.F.) without knowledge of the clinical characteristics of the tumours.Positive tumour cells were quantified and expressed as the percentage of the total number of tumour cells (at least 100 for each case), and assigned to one of 4 categories: 0 (negative); $1-20 \%$ (focal positivity); $21-50 \%$ (moderate positivity); $51-100 \%$ (diffuse positivity).

For the purpose of correlation with clinical data, cases in which immunostaining was undetectable in all cells or present in less than $20 \%$ of the tumour cellswere considered negative (staining patterns negative and focally positive, respectively), whereas samples with $20 \%$ to $50 \%$ or more than $50 \%$ of the cells showingimmunoreactivity were considered positive (staining patterns moderate and diffuse, respectively). However, we caution the reader that these are preliminary, exploratory studies, and that these findings need to be validated using an independent cohort of patients.

For p16, DCC, APC, RB, E-cadherin expression, a case was considered to show an altered phenotype when the expression was absent or focal ( $<20 \%$ of tumour cells), while for p53 and CD10, altered expression was considered in the presence of moderate/diffuse immunostaining (equal or higher of $20 \%$ ) with nuclear and membrane localization, respectively. In the evaluation of $\beta$-catenin positivity, membrane and nuclear localization were considered.

Statistical analysis

All statistical tests were performed using SPSS software (release 17.0). Associations between categorical variables were assessed by chi-squared test; the median value was used as cutoff for age. For analysis of survival, the endpoints 
considered in this study were rates of developing first local recurrence and rate of any disease-related mortality. Local recurrence-free survival and disease-specific survival were modeled using the Kaplan-Meier method and analyzed by the log rank test.

\section{Results}

\section{Histopathology}

The majority of ITACs consisted of a proliferation of cubical and cylindrical cells, with occasional interspersed goblet cells, organized in a papillary exophytic growth, or in tubulo-papillary and solid structures in varying proportions, according to the degree of differentiation of the tumor. Twelve adenocarcinomas (19.4\%) were considered well differentiated, 26 (41.9\%) moderately differentiated, and 8 (12.9\%) poorly differentiated. Of the 62 adenocarcinomas, $16(25.8 \%)$ contained a mucinous component that represented more than $50 \%$ of the lesion. Mucinous adenocarcinomas consisted of large collections of extracellular mucin, which contained or were lined by a proliferation of cuboidal to cylindrical cells with clear to slightly eosinophilic cytoplasm, organized in strands, small glands or alveolar structures defined by fibrovascular septae. In one instance, the tumor consisted of a tubulo-glandular moderately differentiated component and a diffuse pattern of signet ring cells, with intracellular accumulation of mucin, resulting in displacement of the nucleus.

\section{Immunohistochemistry}

The results of the immunohistochemical studies are summarized in Table 2 and illustrated in Figure 1.

\section{Expression of p53, p16, DCC and RB proteins}

Overall, strong and diffuse nuclear staining for p53 in more than $20 \%$ of tumor cells was detected in 38 ITACs (61.3\%). The relative distribution of tumors with p53 overexpression varied according to the histologic subtype, being observed in 6 of 16 mucinous adenocarcinomas (28.3\%) and in 32 of 46 non-mucinous adenocarcinomas 
$(71.7 \%)(p=0.007)$. Loss of $p 16$ protein expression in $>20 \%$ of tumor cells was a frequent event in our series of ITAC $(64.5 \%)$, which, according to the histologic subtype, was present in $13(81.3 \%)$ mucinous adenocarcinomas and in 27 (58.7\%) non-mucinous adenocarcinomas $(p=0.136)$. A concomitant aberrant expression of both proteins was present in 22 ITACs (35.5\%), with a higher frequency in non mucinous adenocarcinomas (40\% vs. $23.5 \%, p=0.37)$.

Twenty-seven ITACs (43.5\%) showed loss of DCC expression in $>20 \%$ of tumour cells, and the aberrant expression was significantly more frequent in mucinous adenocarcinomas than in non mucinous adenocarcinomas (81.3\% vs. $30.4 \%, p=0.001)$. No significant correlation was found between aberrant expression of p53, p16, and DCC. Considering the RB protein, all lesions tested showed diffuse and intense nuclear expression in the majority of tumor cells.

\section{Expression of $A P C$ and $\beta$-Catenin Proteins}

All but one ITACs showed diffuse nuclear and cytoplasmic immunostaining for APC and all cases tested displayed intense and diffuse cell membrane immunoreactivity for $\beta$ catenin.

\section{Expression of E-cadherin and CD10}

Loss of membrane expression of E-cadherin in $>20 \%$ of tumour cells was observed in 28 adenocarcinomas (45.2\%), with a higher relative frequency in mucinous adenocarcinoma (81.3\%) than in non mucinous adenocarcinoma $(32.6 \%)(p=0.001)$. Positivity for CD10 was detected in 27 adenocarcinomas (43.5\%), 5 of which were of the mucinous subtype and 22 of the non mucinous $(p=0.142)$.

\section{Clinico-pathologic correlations}

There was no significant correlation between aberrant protein expression and clinico-pathological parameters, including T stage, local recurrence, lymph node and 
distant metastases, with the exception of loss of DCC which was more frequently observed in advanced stage tumors (53.8\% in stage III-IV vs. $26.3 \%$ in stage I-II; $p=0.05)$.

Table 3 summarizes the correlations between the histologic subtype and the clinical features in our series. Overall, mucinous adenocarcinomas pursued a more aggressive clinical course, presenting more frequently in advanced stage $(p=0.001)$, and showing a higher frequency of local recurrence $(p=0.024)$. Notably, the only two patients who presented lymph node metastases were affected by a mucinous adenocarcinoma, and the rate of distant metastases was higher in this histologic subtype, although the differences were not statistically significant, possibly due to the small number of events.

Analysis of survival using Kaplan-Meier method, showed that mucinous adenocarcinomas had a shorter disease-free interval $(p=0.005)$ and worst disease-free survival $(p<0.001)$ (Figure 2$)$. In addition, advanced T stage was associated with worse prognosis ( $\mathrm{p}=0.014$ for disease free survival, and $\mathrm{p}=0.001$ for overall survival).

Finally, there was no correlation between the histologic subtype and occupational exposure $(p=0.94)$.

\section{Discussion}

Our analysis confirms that the molecular pathways involved in the development of sinonasal ITACs are partially similar to those occurring in colorectal cancer. In keeping with previous molecular analyses, we found that the most commonly altered oncogenes are the $\mathrm{p} 53$ and p16. According to the literature, the overall frequency of TP53 mutations in ITAC varied between $18 \%{ }^{4}$ and $40 \%{ }^{5}$, and considering $\mathrm{LOH}$ at $17 \mathrm{p} 13$, the chromosomal locus of TP53 gene, deregulation of this oncogene was present in $70 \%$ of cases. ${ }^{5}$ In a recent analysis of a large series of wood-dust related sinonasal carcinomas, TP53 mutations were detected in $86 \%$ of the adenocarcinomas. ${ }^{6}$ At the protein level, we observed overexpression of p53 in approximately $60 \%$ of the cases, a rate which is slightly higher than previous investigations. ${ }^{5-6}$ Evidence for 16 gene alterations was found in 
$60 \%$ of ITACs and consisted mainly of promoter methylation, and less frequently in $\mathrm{LOH}$ at the locus $9 p 21$, where the p16 gene is located. ${ }^{5}$ Accordingly, we observed loss of p16 protein expression in $64.5 \%$ of our cases.

Previous studies of sinonasal adenocarcinomas employing CGH and LOH analyses have demonstrated frequent losses at $18 \mathrm{q},{ }^{2,7-9}$ a chromosome region known to harbor genes implicated in colorectal tumorigenesis, such as DCC. This is a putative tumorsuppressor gene that encodes for a transmembrane protein which has been recognized as a netrin-1-dependence receptor that can regulate apoptosis and also likely plays a role in directing cell motility. ${ }^{10-11}$ In colorectal cancer, loss of DCC expression has been related to poorer differentiation, metastases and worse prognosis. ${ }^{12-16}$ Here, we first investigated the expression of DCC in sinonasal ITACs, and we observed that loss of DCC protein is a frequent event, possibly playing an important role in ITAC tumorigenesis. The rate of loss of protein expression is comparable to that of $\mathrm{LOH}$ at $18 \mathrm{q}$ previously reported in sinonasal adenocarcinomas, suggesting that this is likely to be the main mechanism of inactivation of the gene. In addition, loss of DCC was preferentially observed in advanced stage tumors, but no association was found with overall patients' survival in our series.

The alteration of the Wnt signaling pathway, which involves APC and $\beta$-catenin, is regarded as a key event in the development of colorectal cancer, but, in agreement with previous studies, our results indicate that an alteration of the APC- $\beta$-catenin pathway plays a minor role, if any, in the development of sinonasal ITAC. ${ }^{2,17}$

In colorectal adenocarcinoma, loss of the adhesion molecule E-cadherin has been associated with poorly differentiated phenotype, infiltrative growth, development of metastases, and poorer prognosis. In sinonasal ITACs we found, at variance with a previous investigation, ${ }^{17}$ a frequent loss of E-cadherin immunostaining. Several mechanisms can determine loss of E-cadherin expression, including loss of the locus on the long arm of chromosome 16 , gene mutations, and methylation of the promoter. 
According to previous analyses, genetic losses at $16 q 22$ may occur in up to one third of ITACs. ${ }^{9}$ In addition, methylation of the promoter has been observed as a common mechanism of tumor suppressor gene inactivation in ITACs arising in occupationally exposed patients. ${ }^{5}$

CD10 expression has been recently associated with advanced colorectal carcinoma and with the development of liver metastasis, ${ }^{18-20}$ and the incidence of CD10 expression in advanced colorectal carcinoma ranged between $22 \%{ }^{21}$ and $39 \% .{ }^{18}$ In our series of sinonasal ITACs, we found membrane positivity in $43.5 \%$, but no significant association emerged with tumor histologic appearance and clinical behavior.

Colorectal mucinous carcinomas are defined on the basis of the amount of the mucus component in the tumor mass, but they differ from non mucinous carcinomas also for several clinicopathological features and for the associated genetic alterations, suggesting that there may be a 'mucinous pathway of carcinogenesis'. ${ }^{22}$ Indeed, previous studies have demonstrated a limited involvement of p53 suppressor gene in the development of colorectal mucinous adenocarcinomas, and have led to the hypothesis that these tumors might be developing along a pathway independent from this gene. ${ }^{22}$ This hypothesis is supported by the observation that colorectal mucinous carcinomas develop in vitro without alteration of p53 gene or its expression, ${ }^{23,24}$ and by several reports indicating that overexpression of p53 protein in tumor tissue as well as gene mutations are less frequent than in non mucinous adenocarcinoma. ${ }^{25-27}$ In addition, low frequency of p53 overexpression has been documented in mucinous carcinomas of the breast,$^{28}$ ovary,${ }^{29}$ and pancreas. ${ }^{30}$ In agreement with these studies, we observed significantly lower levels of p53 expression in mucinous than in non-mucinous ITACs. Another similarity with colorectal adenocarcinomas was the presence of a significantly higher rate of aberrant E-cadherin expression in mucinous than in non mucinous ITACs. Indeed, hypermethylation of the E- 
cadherin gene and abnormal protein expression have been observed at a higher rate in mucinous colorectal adenocarcinomas. ${ }^{31}$

Other molecular abnormalities appear to occur at different rates in sinonasal mucinous ITACs in comparison with the colorectal counterparts. Loss of p16 was significantly less common in colorectal mucinous tumors than in nonmucinous tumors, ${ }^{32}$ while in our analysis we did not observe any significant difference between the two groups, although the rate of $\mathrm{p} 16$ loss was lower in mucinous adenocarcinomas. In addition, DCC gene expression has been associated with mucus-producing goblet cells in normal mucosa and with mucinous phenotype in colorectal adenocarcinoma. ${ }^{33}$ This is in contrast with our observation that mucinous ITACs show a higher rate of loss of DCC expression than non mucinous tumors.

In conclusion, mucinous ITACs of the sinonasal tract present in advanced stage, have a shorter disease free interval and overall survival, and appear to develop along different molecular pathways than non-mucinous adenocarcinomas. At the molecular level, sinonasal and colorectal mucinous adenocarcinomas share a low frequency of p53 alteration and a frequent loss of E-cadherin, while loss of DCC appears to be relevant only in sinonasal tumours. We suggest that these molecular features may explain to some extenta worse prognosis established for patients diagnosed with mucinous ITAC compared with non-mucinous ITAC, and further work is necessary to explore this possibility.

\section{Acknowledgements}

This study was supported by a grant from Istituto Toscano Tumori (ITT). 


\section{References}

1. Franchi A, Santucci M, Weing B. Adenocarcinomas. In: Barnes L, Evenson JW, Reichart P, Sidransky D eds. World health organization classification of tumours. Pathology and genetics of head and neck tumours. Lyon: IARC; 2005. p. 20-3.

2. Frattini M, Perrone F, Suardi S, et al. Phenotype-genotype correlation: challenge of intestinaltype adenocarcinoma of the nasal cavity and paranasal sinuses. Head Neck. 2006; 28; 909915.

3. Franchi A, Massi D, Palomba A, Biancalani M, Santucci M. CDX-2, cytokeratin 7 and cytokeratin 20 immunohistochemical expression in the differential diagnosis of primary adenocarcinomas of the sinonasal tract. Virchows Arch. 2004; 445; 63-67.

4. Wu TT, Barnes L, Bakker A, Swalsky PA, Finkelstein SD. K-ras-2 and p53 genotyping of intestinal-type adenocarcinoma of the nasal cavity and paranasal sinuses. Mod Pathol 1996; 9;199-204.

5. Perrone F, Oggionni M, Birindelli S, et al. TP53, p14ARF, p16INK4a and H-ras gene molecular analysis in intestinal-type adenocarcinoma of the nasal cavity and paranasal sinuses. Int. J. Cancer 2003; 105; 196-203.

6. Holmila R, Bornholdt J, Heikkilä P, et al. Mutations in TP53 tumor suppressor gene in wood dust-related sinonasal cancer. Int. J. Cancer 2009 Nov 30. [Epub ahead of print]

7. Ariza M, Llorente JL, Alvarez-Marcas C, et al. Comparative Genomic Hybridization in primary sinonasal adenocarcinomas. Cancer 2004; 100; 335-341.

8. Korinth D, Pacyna-Gengelbach M, Deutschmann N, et al. Chromosomal imbalances in wood dust-related adenocarcinomas of the inner nose and their associations with pathological parameters. J. Pathol. 2005; 207; 207-215.

9. Hermsen MA, Llorente JL, Pérez-Escuredo J, et al. Genome-wide analysis of genetic changes in intestinal-type sinonasal adenocarcinoma. Head Neck 2009; 31; 290-297.

10. Pierceall WE, Reale MA, Candia AF, et al. Expression of a homologue of the deleted in 
colorectal cancer (DCC) gene in the nervous system of developing Xenopus embryos. Dev. Biol. 1994; 166; 654-665.

11. Keino-Masu K, Masu M, Hinck L, et al. Deleted in colorectal cancer (DCC) encodes a netrin receptor. Cell 1996; 87; 175-185.

12. Sun XF, Rutten $\mathrm{S}$, Zhang $\mathrm{H}$, et al. Expression of deleted in colorectal cancer gene is related to prognosis in DNA diploid and low proliferative colorectal adenocarcinoma. J Clin. Oncol. 1999; $17 ; 1745-1750$.

13. Jen J, Kim H, Piantadosi S, et al. Allelic loss of chromosome $18 q$ and prognosis in colorectal cancer. N. Engl. J. Med. 1994; 331; 213-221.

14. Ogunbiyi OA, Goodfellow PJ, Herfarth $\mathrm{K}$, et al. Confirmation that chromosome $18 \mathrm{q}$ allelic loss in colon cancer is a prognostic indicator. J. Clin. Oncol. 1998; 16; 427-433.

15. Lanza G, Matteuzzi M, Gafa R, et al. Chromosome $18 q$ allelic loss and prognosis in stage II and III colon cancer. Int. J. Cancer 1998; 79; 390-395.

16. Aschele C, Debernardis D, Lonardi S, et al. Deleted in colon cancer protein expression in colorectal cancer metastases: a major predictor of survival in patients with unresectable metastatic disease receiving palliative fluorouracil-based chemotherapy. J. Clin. Oncol. 2004; 22; 3758-3765.

17. Perez-Ordonez B, Huynh NN, Berean KW, Jordan RCK. Expression of mismatch repair proteins, $\beta$ catenin, and $\mathrm{E}$ cadherin in intestinal-type sinonasal adenocarcinoma. J. Clin. Pathol. $2004 ; 57 ; 1080-1083$.

18. Fujimoto $\mathrm{Y}$, Nakanishi $\mathrm{Y}$, Sekine S, et al. CD10 expression in colorectal carcinoma correlates with liver metastasis. Dis. Colon Rectum 2005; 48; 1883-1889.

19. Ohji Y, Yao T, Eguchi T et al. Evaluation of risk of liver metastasis in colorectal adenocarcinoma based on the combination of risk factors including CD10 expression: multivariate analysis of clinicopathological and immunohistochemical factors. Oncol. Rep. 
$2007 ; 17 ; 525-530$.

20. Iwase T, Kushima R, Mukaisho K, Mitsufuji S, Okanoue T, Hattori T. Overexpression of CD10 and reduced MUC2 expression correlate with the development and progression of colorectal neoplasms. Pathol. Res. Pract. 2005; 201; 83-91.

21. Yao T, Tsutsumi S, Akaiwa Y et al. Phenotypic expression of colorectal adenocarcinomas with reference to tumor development and biological behavior. Jpn. J. Cancer Res. 2001; 92; 755761.

22. Hanski C. Is mucinous carcinoma of the colorectum a distinct genetic entity? Br. J. Cancer. $1995 ; 72 ; 1350-1356$.

23. Markowitz SD, Myeroff L, Cooper MJ, et al. A benign cultured colon adenoma bears three genetically altered colon cancer oncogenes, but progresses to tumorigenicity and transforming growth factor-beta independence without inactivating the p53 tumor suppressor gene. J. Clin. Invest. 1994; 93; 1005-1013.

24. Williams AC, Browne SJ, Yeudal WA, et al. Molecular events including p53 and k-ras alterations in the in vitro progression of a human colorectal adenoma cell line to an adenocarcinoma. Oncogene 1993; 8; 3063-3072.

25. Campo E, de la Calle-Martin O, Miquel R, et al. Loss of heterozygosity of p53 gene and p53 protein expression in human colorectal carcinomas. Cancer Res. 1991; 51; 4436-4442.

26. Lanza G Jr, Maestri I, Dubini A, et al. p53 expression in colorectal cancer: relation to tumor type, DNA ploidy pattern and short-term survival. Am. J. Clin. Pathol. 1996; 105; 604-612.

27. Hanski C, Tiecke F, Hummel M, et al. Low frequency of p53 gene mutation and protein expression in mucinous colorectal carcinomas. Cancer Lett. 1996; 103; 163-170.

28. Lipponen $\mathrm{P}$, Ji H, Aaltomaa S, et al. p53 protein expression in breast cancer as related to histopathological characteristics and prognosis. Int. J. Cancer 1993; 55; 51-56.

29. Frumovitz M, Schmeler KM, Malpica A, Sood AK, Gershenson DM. Unmasking the 
complexities of mucinous ovarian carcinoma. Gynecol. Oncol. 2010; 117; 491-496.

30. Hoshi T, Imai M, Ogawa K. Frequent K-ras mutations and absence of p53 mutations in mucinproducing tumors of the pancreas. J. Surg. Oncol. 1994; 55; 84-91.

31. Kanazawa T, Watanabe T, Kazama S, Tada T, Koketsu S, Nagawa H. Poorly differentiated adenocarcinoma and mucinous carcinoma of the colon and rectum show higher rates of loss of heterozygosity and loss of E-cadherin expression due to methylation of promoter region. Int. J. Cancer 2002; 102; 225-229.

32. Ogino S, Brahmandam M, Cantor M, et al. Distinct molecular features of colorectal carcinoma with signet ring cell component and colorectal carcinoma with mucinous component. Mod. Pathol. 2006; 19; 59-68.

33. Hedrick L, Cho KR, Fearon ER, Wu TC, Kinzler KW, Vogelstein B. The DCC gene product in cellular differentiation and colorectal tumorigenesis. Genes Dev. 1994; 8; 1174-1183. 


\section{Legends for Figures}

Figure 1. Representative immunophenotypic profiles of the tumor-related gene products examined in the present study. A: P53, deleted in colon cancer (DCC), and E-cadherin were differentially expressed in mucinous (upper line) and non-mucinous (lower line) adenocarcinomas. B: RB, p16, APC, $\beta$-catenin, and CD10 showed similar expression levels in the two histologic subtypes (upper line: mucinous adenocarcinomas; lower line: non-mucinous adenocarcinomas)

Figure 2. Disease-free (A) and overall survival (B) in 62 patients affected by intestinal-type adenocarcinoma. Kaplan-Meier survival curves depicting the disease-related disease-free survival and mortality stratified by histologic subtype. 
Table 1. Summary of the features of the antibodies employed in this study.

\begin{tabular}{|c|c|c|c|}
\hline Antibody & Clone and Source & Titration & Antigen Retrieval \\
\hline p16 & $\begin{array}{l}\text { 16P04, Cell Marque Co., } \\
\text { Rocklin, CA }\end{array}$ & $\begin{array}{c}\text { prediluted } \\
32 \text { minutes, } 37^{\circ} \mathrm{C}\end{array}$ & $\mathrm{CC} 1,30$ minutes \\
\hline$\overline{D C C}$ & $\begin{array}{c}\text { G97-499, BD Biosciences, San } \\
\text { Josè, CA }\end{array}$ & $\begin{array}{c}1: 100 \\
30 \text { minutes RT }\end{array}$ & EDTA, 20 minutes \\
\hline E-cadherin & $\begin{array}{c}\text { ECH6, Cell Marque Co., } \\
\text { Rocklin, CA }\end{array}$ & $\begin{array}{c}\text { prediluted } \\
28 \text { minutes, } 37^{\circ} \mathrm{C}\end{array}$ & $\mathrm{CC} 1,30$ minutes \\
\hline APC & $\begin{array}{c}\text { Polyclonal, Santa Cruz } \\
\text { Biotechnology, Santa Cruz, CA }\end{array}$ & $\begin{array}{c}1: 300 \\
60 \text { minutes RT } \\
\end{array}$ & EDTA, 20 minutes \\
\hline Beta catenin & $\begin{array}{l}\text { 14, Cell Marque Co., } \\
\text { Rocklin, CA }\end{array}$ & $\begin{array}{c}\text { prediluted } \\
32 \text { minutes, } 37^{\circ} \mathrm{C} \\
\end{array}$ & $\mathrm{CC} 1,60$ minutes \\
\hline CD10 & $\begin{array}{l}\text { 56C8, Cell Marque Co., } \\
\text { Rocklin, CA }\end{array}$ & $\begin{array}{c}\text { prediluted } \\
32 \text { minutes, } 37^{\circ} \mathrm{C}\end{array}$ & CC1, 30 minutes \\
\hline p53 & $\begin{array}{l}\text { DO7, Ventana, } \\
\text { Tucson, AZ }\end{array}$ & $\begin{array}{c}1: 40 \\
60 \text { minutes RT }\end{array}$ & CC1, 60 minutes \\
\hline $\mathrm{RB}$ & $\begin{array}{c}\text { 13A10, Novocastra, } \\
\text { Newcastle-upon-Tyne, UK }\end{array}$ & $\begin{array}{c}1: 30 \\
60 \text { minutes RT }\end{array}$ & $\begin{array}{c}35 \text { minutes MW } \\
\text { citrate buffer ph } 6.0\end{array}$ \\
\hline
\end{tabular}

CC: cell conditioning; RT: room temperature 
Table 2. Correlation between histologic subtype and immunohistochemical findings in 62 cases of sinonasal intestinal type adenocarcinoma.

\begin{tabular}{|l|c|c|c|}
\hline & Mucinous (n=16) & Non-mucinous (n=46) & P \\
\hline p53 (>20\%) & $6(28.3 \%)$ & $33(71.7 \%)$ & 0.007 \\
\hline p16 (<20\%) & $13(81.3 \%)$ & $27(58.7 \%)$ & 0.136 \\
\hline DCC $(<20 \%)$ & $13(81.3 \%)$ & $14(30.4 \%)$ & 0.001 \\
\hline RB $(<20 \%)$ & 0 & 0 & NA \\
\hline APC $(<20 \%)$ & $1(6.2 \%)$ & 0 & 1 \\
\hline -catenin $(>20 \%)$ & $16(100 \%)$ & $46(100 \%)$ & NA \\
\hline E-cadherin $(<20 \%)$ & $13(81.3 \%)$ & $15(32.6 \%)$ & 0.001 \\
\hline CD10 $(>20 \%)$ & $4(25.0 \%)$ & $23(50.0 \%)$ & 0.142 \\
\hline
\end{tabular}


Table 3. Correlation between histologic subtype and clinical features in 62 sinonasal intestinal type adenocarcinomas.

\begin{tabular}{|l|c|c|c|}
\hline & Mucinous (n=16) & Non-mucinous (n=46) & $\mathbf{P}$ \\
\hline Age (median) & 62.5 years & 63.5 years & 0.197 \\
\hline Sex (M:F) & $16: 0$ & $39: 7$ & 0.173 \\
\hline $\begin{array}{l}\text { Occupational exposure } \\
\text { None } \\
\text { Leatherworker } \\
\text { Woodworker }\end{array}$ & $\begin{array}{l}4(26.6 \%) \\
7(46.8 \%)\end{array}$ & $\begin{array}{c}9(22.5 \%) \\
19(47.5 \%) \\
12(30.0 \%)\end{array}$ & 0.94 \\
\hline T stage ${ }^{* *}$ (III-IV) & $15(100 \%)$ & $24(55.8 \%)$ & 0.001 \\
\hline Lymph node metastasis $^{* *}$ & $2(13.3 \%)$ & 0 & 0.068 \\
\hline Distant metastasis & $3(20.0 \%)$ & $4(8.7 \%)$ & 0.35 \\
\hline Local recurrence $^{* *}$ & $11(85.7 \%)$ & $20(44.2 \%)$ & 0.024 \\
\hline Proportion disease free at 5 years & $8.3 \%$ & $43.3 \%$ & 0.005 \\
\hline Proportion surving at 5 years $^{* *}$ & $7.7 \%$ & $55.7 \%$ & $<0.001$ \\
\hline
\end{tabular}

*available for 55 patients; ${ }^{* *}$ available for 58 patients 
p53

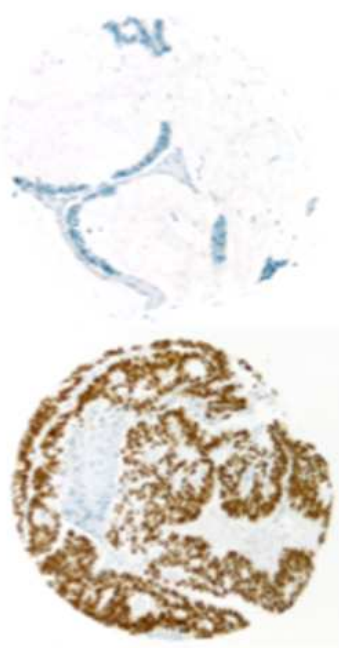

A
DCC

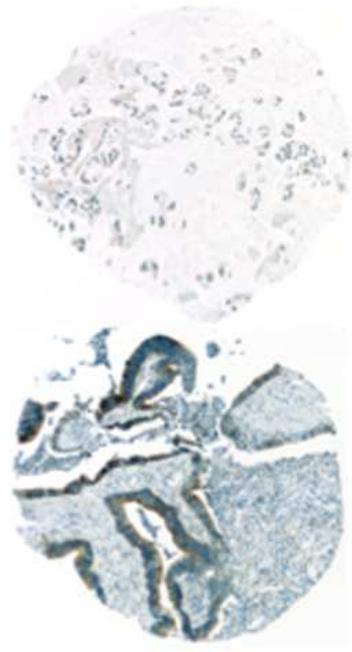

$80 \times 63 \mathrm{~mm}(300 \times 300$ DPI $)$

\section{E-Cadherin}

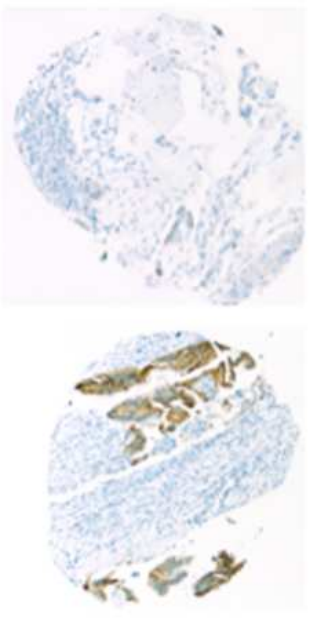



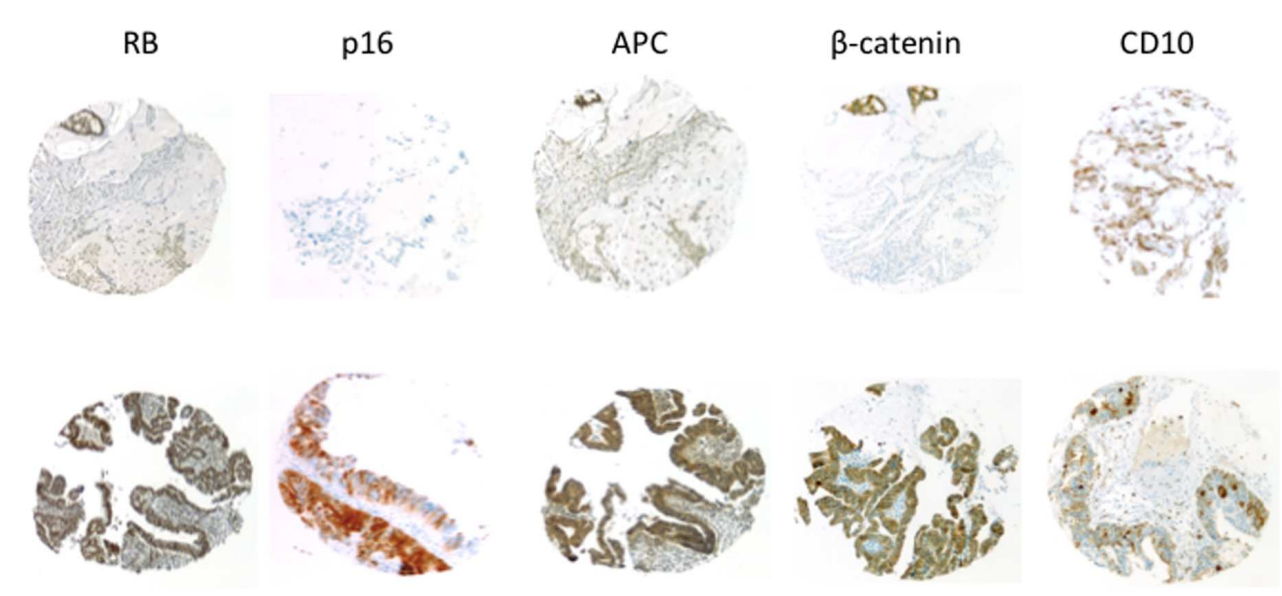

B

$160 \times 83 \mathrm{~mm}(300 \times 300$ DPI $)$ 


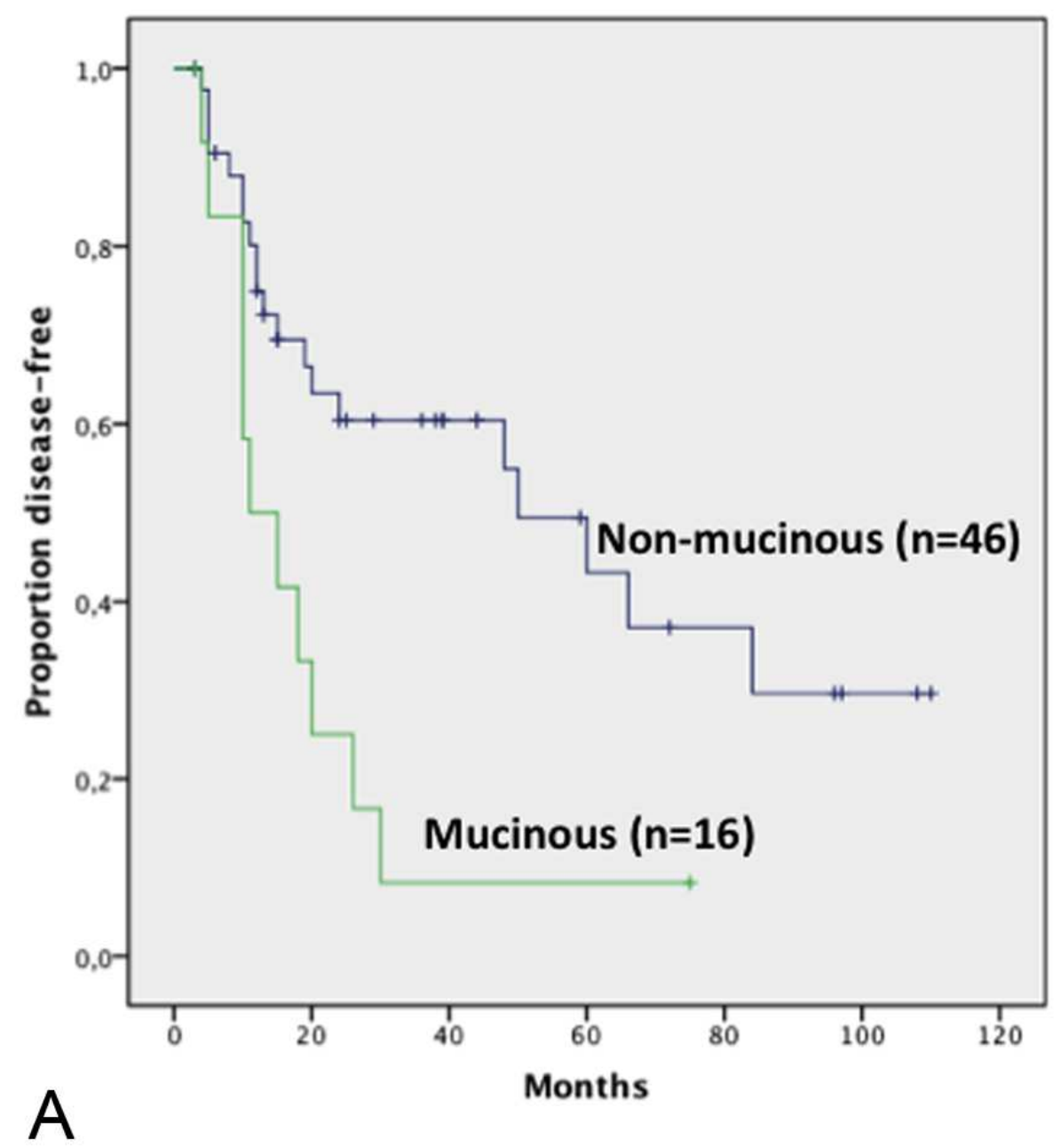

$80 \times 83 \mathrm{~mm}(300 \times 300$ DPI $)$ 


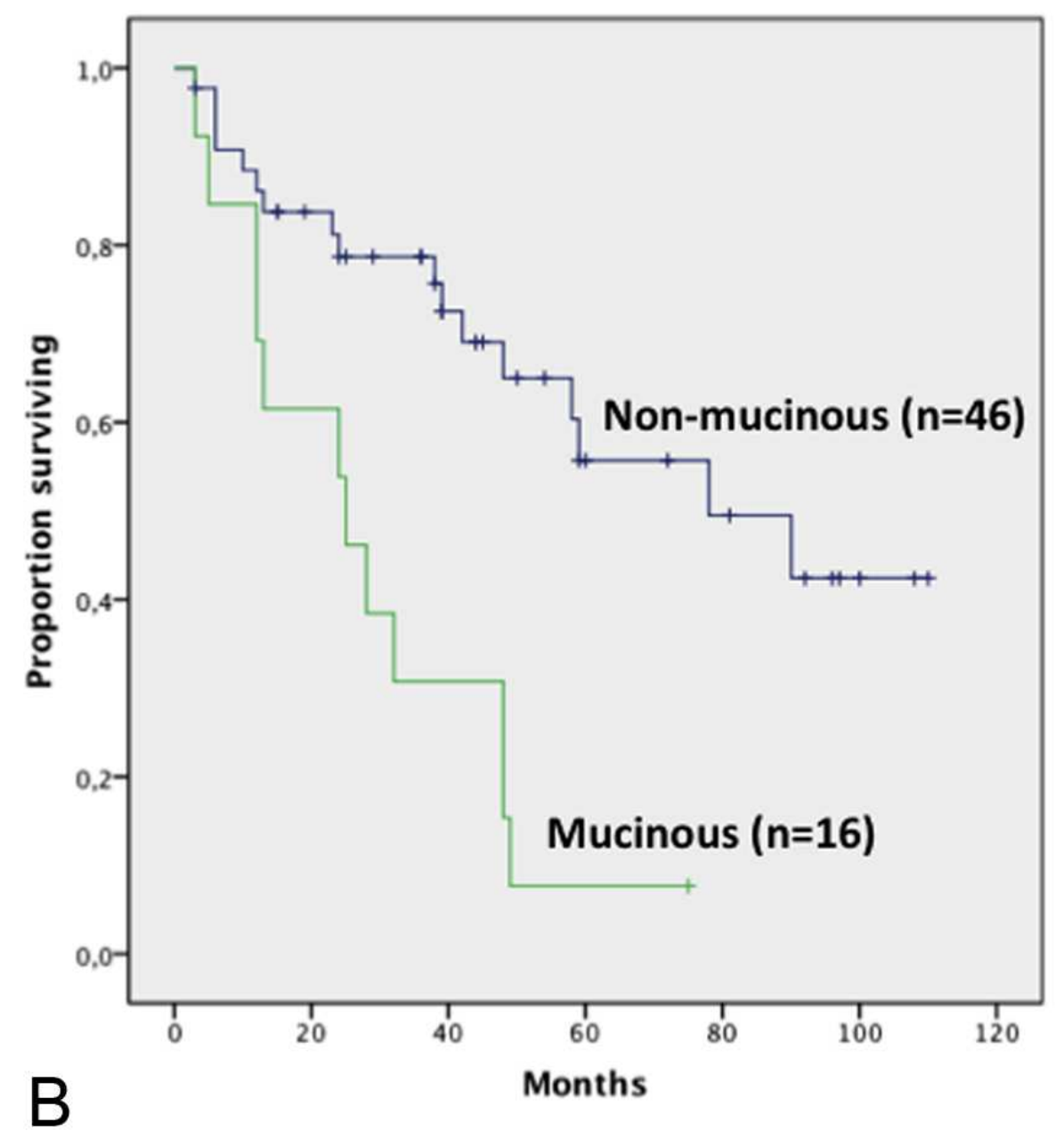

$80 \times 81 \mathrm{~mm}(300 \times 300$ DPI $)$ 